\title{
The cost of convenience
}

\section{Marisa Bidois}

\begin{abstract}
Marisa Bidois was appointed to her role as CEO of the Restaurant Association of New Zealand in 2011 and has now led the association for eight years. Before becoming CEO, Bidois was professional development manager for the association's Auckland function facility, Taste, and looked after its employment relations and legal queries for four years. She has also worked outside of the industry, but always makes her way back because of the people from all walks of life who gather in the hospitality industry.
\end{abstract}

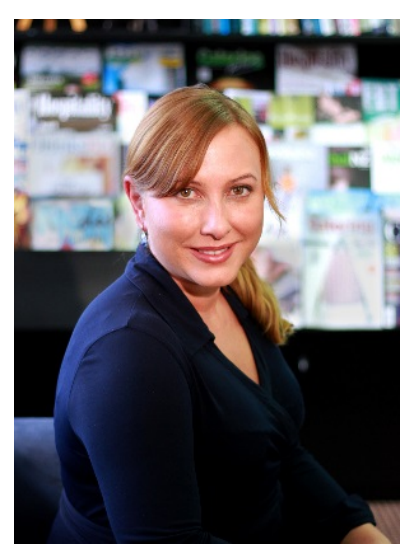

Hospitality businesses in New Zealand are seeing fewer and fewer payments made by cash, as customers opt for the convenience of paying their bill electronically. If customers love the convenience of paying by credit card, who should be responsible for the cost of this convenience - the business or the customer?

In a Restaurant Association survey conducted at the end of last year, members overwhelmingly $(71 \%)$ indicated that the use of cash by customers is declining, with a Mastercard New Zealand survey last year backing this up. This widespread adoption of electronic payment by consumers sees merchants bearing the significant cost of the transaction through their merchant fees. New Zealand merchants pay substantially more to process credit and contactless debit card transactions than their counterparts in Australia and the UK (on average, New Zealand merchants pay merchant service fees of around 1.4\%, while in Australia it is around $0.85 \%$, according to estimates by COVEC and data from the Reserve Bank of Australia). Restaurant Association members typically pay even higher - between $1.8 \%$ and $2 \%$ in fees for each credit card transaction; members say they are charged the same rate for any card type. Forty-two percent have a 'fixed bundled rate', although another $26 \%$ say they are charged a split rate for credit card and debit cards. Only $5 \%$ have an 'unbundled' merchant fee, where different types of cards are charged different fees and merchants pay this cost plus an acquiring service fee from the bank.

There are undoubtedly advantages for businesses in accepting electronic payments, primarily in the speed of the transaction - particularly with several customers waiting to pay - and the speed in which the payment is deposited into your bank account. However, it comes at a large cost, which is challenging for an industry that runs on very small margins already. One member pointed out in the Association's recent survey:

As the average return in New Zealand is $6 \%$ net profit, the banks are effectively charging 1/3 of the profit of the average business, which is diabolical. With technology advancements their costs have gone down but charges have gone up, clearly shown in their bottom line profits. It is a collective monopoly like a lot of big business in New Zealand. (Restaurant Association member)

Of our members, $66 \%$ say they would switch banks if they could receive a saving equating to an overall $2.5-5 \%$ reduction in the cost of accepting credit cards. Currently though, short of refusing to accept credit card payments, it is 
difficult to avoid merchant fees. Emerging payment options and growing trends via NFC (Near Field Communication) capable mobile phones (such as ApplePay, GooglePay and Digital Wallets) are now more widely available. Whilst offering convenience and arguably faster transaction speed, these payment methods offer no relief to the fee incurred by a business for acceptance.

Alternative payment solutions now exist in New Zealand, but there are few choices. To date, most are aimed at the Chinese market, with payment methods restricted to tourist and student visitors, and immigrants retaining banking capability in their country of origin. The Restaurant Association's survey indicated that only $24 \%$ of members currently accept other payment channels like China Union Pay, Alipay or WeChat. In reality these alternative payment solutions currently only form a small portion of the total volume of transactions a business processes, so will not generate any meaningful reduction in the total costs of cards/payment processing.

Surcharging, however, is a way for operators to offset the merchant fee imposed upon them by the banks. Surcharging simply means a charge to cover a merchant's cost for processing a credit card. They are now being used by increasing numbers of tourism and hospitality businesses. Feedback from member businesses is that there is little reaction or negative feedback from customers. In the 2018 survey, a Restaurant Association member commented:

We added a surcharge to cover the transaction fee on credit cards and have had no complaints. It's just a matter of cents and gives us an opportunity to explain that we have always worn the cost of the surcharges but this is increasingly difficult.

Feedback from some members is that they find the practice unfriendly and others would prefer to incorporate this fee into their menu pricing structure, as this member pointed out: "I don't care about the cost. It is added into the budgets and is picked up at menu price changes time, so it is paid for by the customer anyway." Individual businesses need to decide if a surcharge would create tension in the business/customer relationship; however, it is reassuring to know that, if a business does decide to add a surcharge, it is becoming a far more mainstream option than it used to be.

From a legal standpoint, merchants are required under the Fair Trading Act to ensure representations around their card payment fees are accurate and not misleading. This means if you are being charged a 1.8\% merchant fee by your bank, it is not reasonable to apply a $3 \%$ credit card convenience fee to your customer. We've noticed some merchants prefer to pass on only a portion of the cost with a surcharge - say $1 \%$ - as a cost recovery practice. For a $\$ 100$ bill, that is just a $\$ 1$ addition to the bill for the consumer.

The payments landscape is changing rapidly, and in the future new technology will dramatically change the way we pay and receive payments. In the meantime, the Restaurant Association are developing further information for members around surcharging, with implementation and training for staff. We'll also continue advocating on behalf of members to ensure the payment system delivers good outcomes for both consumers and our member merchants.

\section{Corresponding author}

Marisa Bidois can be contacted at: marisa@restaurantnz.co.nz 